\title{
SANTRIPRENEUR: Program Peningkatan Kemampuan Berwirausaha Santri Pondok Pesantren melalu Pelatihan Sablon Digital
}

\author{
Muhammad Hasyim Ibnu Abbas ${ }^{1}$, Hadi Sumarsono 2 , Yogi Dwi Satrio ${ }^{3}$, Magistyo Purboyo \\ Priambodo $^{4}$ \\ 1,2,3,4 Fakultas Ekonomi, Universitas Negeri Malang, Indonesia \\ e-mail:muhammad.hasyim.fe@um.ac.id.
}

\begin{abstract}
Community Service is a program aiming to transfer the development of science and technology from the Higher Education institutions to the community to improve the welfare of the community. In this entrepreneurship development program, we, the team of community service, will conduct production training in the creative industry sector in the form of digital printing expertise at Anwarul Huda Islamic Boarding School in Malang City. Through this community service program which will be conducted by Lecturers from the UM Research and Community Service Institute (LP2M), in collaboration with practitioners in the field of creative industries, new entrepreneurs called santripreneur in the field of creative industries are expected to be born, and can manage businesses better. This program divided into three activities namely Socialization, Training and Assistance. The first step, socialisation, was conducted to attract students who are interested in participating in the training. The next activity, Training, is conducted to increase the skill of students in one of creative industry sector. The last of the program is accompaniment which has an aim to help the students create a printing business in the Islamic boarding school.
\end{abstract}

Keywords: Santripreneur, Entrepreneurship, Creative Industry, Digital Printing

\begin{abstract}
Abstrak
Pengabdian Kepada Masyarakat merupakan suatu program dengan misi menerapkan pengembangan IPTEK dari perguruan tinggi kepada masyarakat untuk mendukung dan meningkatkan kesejahteraan masyarakat. Dalam program pengembangan kewirausahaan ini, tim melakukan pelatihan produksi dalam sektor industri kreatif berupa keahlian sablon pada Pondok Pesantren Anwarul Huda Kota Malang. Para santri dipandang perlu diberikan pendampingan untuk meningkatkan kemandirian ekonomi. Selain itu, hal ini juga didukung dengan Pondok Pesantren Anwarul Huda Kota Malang yang memperkenankan para santri untuk berwirausaha untuk menciptakan santri yang mandiri secara ekonomi. Melalui program pengabdian kepada masyarakat ini yang akan dilaksanakan oleh Dosen dari Lembaga Penelitian dan Pengabdian Masyarakat (LP2M) UM, bekerjasama dengan praktisi bidang industri kreatif, diharapkan lahir wirausaha-wirausaha baru dan santripreneur dalam bidang industri kreatif, serta dapat mengelola usaha dengan lebih baik. Kegiatan ini terbagi menjadi empat tahap yakni observasi analisis kebutuhan mitra, Sosialisasi, Pelatihan, dan Pendampingan.
\end{abstract}

Kata Kunci: Santripreneur, Kewirausahaan, Industri Kreatif, Digital Printing

\section{PENDAHULUAN}

Pendidikan merupakan salah satu investasi yang sangat penting bagi para generasi muda sebelum mereka memegang estafet pembangunan manusia yang lebih baik. Sebegitu pentingnya pendidikan, islam sebagai agama universal bahkan mewajibkan para pemeluknya hingga sampai akhir kehidupannya. Berabad-abad sebelum lahirnya revolusi industry di eropa, islam telah mengelola system pendidikan formal bagi pemeluknya dari tingkat anak-anak. Sistem pendidikan formal pada saat itu dikelola dengan dana swadaya dari orang tua siswa dan sumbangan dari orang yang lebih mampu.

Sistem pendidikan islam di Indonesia sikembangkan melalui sebuah lembaga yang dinamakan pesantren. Sejarah mencatat bahwa pesantren sudah berdiri bahkan sebelum Negara Kesatuan 
Republik Indonesia berdiri. Sehingga, bias dikatakan bahwa pesantren adalah produk dan warisan budaya Indonesia dan pesantren juga telah diakui mempunyai peran yang sangat besar dalam dunia pendidikan di Indonesia (Haedari, 2007). Sampai sekarang, pesantren masih menjadi pusat pendidikan islam di Indonesia.

Unsur agama yang sangat erat dan melekat dengan pesantren memunculkan sebuah paradoks dalam pandangan masyarakat tentang investasi sumber daya manusia di bidang pendidikan (Suyatman, 2017). Masyarakat umum masih menanggap bahwa pesantren hanyalah sarana investasi pendidikan yang hanya ditujukan untuk meningkatkan aspek sikap dan religiusitas yang berorientasi pada kehidupan setelah mati. Di sisi lain, masyarakat juga masih menganggap bahwa untuk meningkatkan keadaan perekonomian mereka, maka meraka harus menyekolahkan anak-anak mereka di sekolah-sekolah umum.

Pandangan tersebut sebenarnya merupakan pandangan yang keliru namun sudah terlanjur tertanam pada sebagian besar masyarakat Indonesia. Sejatinya, pesantren selain merupakan lembaga pendidikan untuk memperdalam ilmu agama juga mempunyai potensi dalam pengembangan perkonomian (Muttaqin, 2016). Ikatan kuat antara santri dan para guru serta kiyai mereka sebenarnya merupakan modal social yang besar sebagai bagian dari modal dalam pengembangan ekonomi (Rudi \& Haikal, 2014). Jika dilihat dari sisi sejahranya, pesantren merupakan lembaga pendidikan yang mandiri secara ekonomi sejak awal berdirinya. Pesantren memiliki mekanisme dan system kerja yang sangat khas dalam pemenuhan kebutuhan mereka sendiri.

Di era modern sekarang ini, pesantren di Indonesia dengan berbagai macam latar belakangnya banyak yang sudah membuktikan kepiawaiannya dalam mengelola kemadirian ekonominya (Wadi, 2018). Sebagai contoh di Jawa Timur, pesantren Sidogiri Pasuruan memiliki outlet minimarket yang tersebar di berbagai daerah khususnya di Kabupaten dan Kota Pasuruan sendiri. Selain itu, di Kota Malang terdapat pondok pesantren yang mulai membangun kemandirian ekonominya yakni pesantren Anwarul Huda yang saat ini telah memiliki usaha air minum dalam kemasan.

Pondok pesantren Anwarul Huda (PPAH) diresmikan pada tanggal 2 Oktober 1997 oleh K.H.M. Baidlowi Muslich yang sampai sekarang masih menjadi pengasuh PPAH. Telah disebutkan di atas, bahwa pesantren Anwarul Huda telah memiliki usaha Air Minum dalam kemasan yang menjadi salah satu sumber pendanaan pesantren yang dijalankan oleh para santrinya. Selain itu, Pengasuh juga memberikan berbagai macam pendidikan dan peningkatan skill para santri melalui program pelatihanpelatihan seperti Pembuatan Tempe Kacang, Pelatihan Pembuatan Kripik, dan lain sebagainya. Dengan demikian, bisa dikatakan bahwa PPAH selain mengelola dan menyelenggarakan pendidikan di bidang agama, juga peduli terhadap keberlangsungan kehidupan para santri di kemudian hari.

Berbekal latar belakang tersebut, kami tertarik melakukan kegiatan Pengabdian kepada Masyarakat terkait dengan pemberdayaan para santri di PPAH. Kegiatan PkM kami bertujuan untuk meningkatkan keterampilan santri PPAH di bidang industry kreatif. Industri Kreatif dipilih karena pada era sekarang sedang massif perkembangannya sehingga para santri dipandang perlu mempunyai skill di bidang ekonomi kreatif. Selain itu, hasil observasi awal kunjungan ke PPAH menunjukkan bahwa sebenarnya banyak santri yang menguasi aplikasi di bidang seni dan desain, namun masih belum tahu bagaimana cara memanfaatkan keahlian tersebut menjadi sesuatu yang menghasilkan income generating. Oleh karena itu, kami tim dosen dari Universitas Negeri Malang, bekerja sama dengan praktisi di bidang digital printing, 
memutuskan untuk mengadakan pelatihan digital printing kepada para santri PPAH dengan harapan skill santri dalam bidang seni rupa tersebut bias dimanfaatkan dengan sebaik-baiknya.

\section{METODE}

Metode pelaksanaan Pengabdian ini pada intinya menggunakan pendekatan partisipatif, dimana peran serta para peserta diharapkan lebih besar dalam pelatihan ini. Adapun tahapan pengabdian ini dibedakan menjadi 4 tahapan penting:

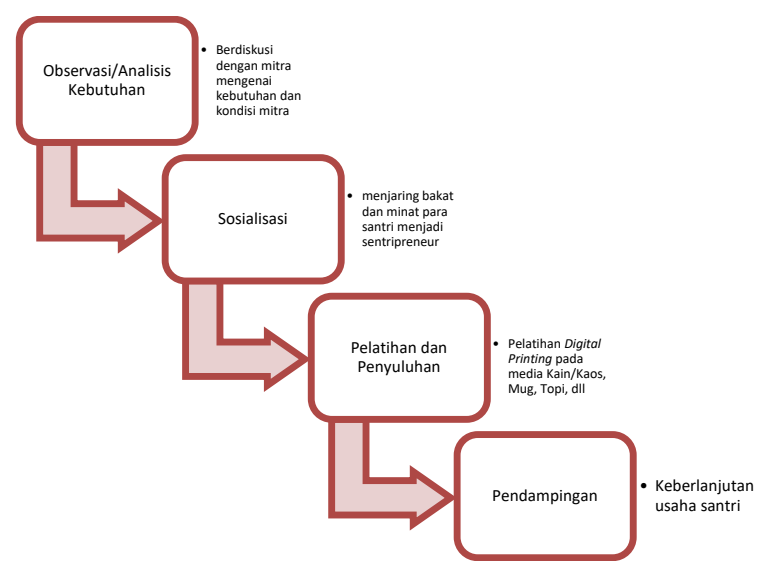

Gambar 1. Tahapan Kegiatan

1) Observasi/Analisis kebutuhan Mitra

Tahap observasi dilakukan untuk menggali informasi terkait kondisi terkini dari Pondok Pesantren Anwarul Huda (PPAH). Pada tahap ini dilakukan diskusi dan tanya-jawab tentang program apa yang cocok untuk diterapkan untuk para santri PPAH.

2) Sosialisasi

Tahap sosialisasi berisikan kegiatan mengumpulkan seluruh santri yang ada di PPAH untuk kemudian dilakukan penjaringan para santri yang berminat untuk mengikuti pelatihan digital printing. Tahapan ini bermaksud agar metode partisipatif bias diterapkan secara maksimal karena hanya yang berminat saja yang akan mengikuti tahapan-tahapan selanjutnya.

3) Pelatihan dan Penyuluhan

Tahapan ketiga merupakan tahapan inti dari program pengabdian ini. Dalam tahapan ini, santri akan dibekali dengan pengetahuan untuk digital printing di media seperti kaos, mug, topi, dan lain sebagainya. Selain itu, siswa juga akan dibekali kemampuan manajemen pengelolaan usaha. Alat yang digunakan dalam pelatihan ini adalah mesin press 5 in 1 seperti gambar berikut:

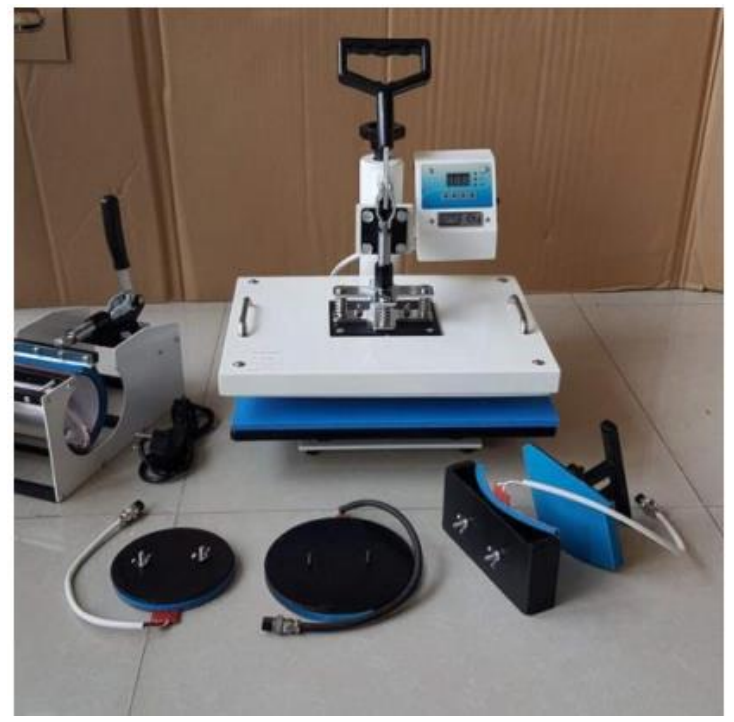

Gambar 2. Mesin Press 5 in 1

4) Pendampingan

Kegiatan pendampingan dilaksanakan sebagai tindak lanjut dari kegiatan pelatihan. Dalam kegiatan ini, tim akan mendampingi kelompok santri yang berminat berwirausaha (santripreneur) di bidang digital printing untuk membentuk usaha di bidang tersebut dari awal pembentukan sampai konsultasi terkait pengelolaan organisasi perusahaan.

\section{HASIL DAN PEMBAHASAN}

\section{Tahap Sosialisasi}

Tahap sosialisasi dilaksanakan pada pertengahan bulan Juli yang dimaksudkan untuk menjaring para santri yang memang berniat untuk mengikuti rangkaian kegiatan dalam pelaksanakan pengabdian ini. Acara sosialisasi dihadiri oleh hampir seluruh santri PPAH yang berjumlah kurang lebih 350 santri dan 
bertempat di Gedung Halaqoh PPAH. Materi yang diberikan pada tahap ini adalah materi tentang pentingnya berwirausaha dan menggali potensi ekonomi pondok pesantren serta pemberitahuan tentang rangkaian kegiatan yang akan dilaksanakan oleh tim di Pondok Pesantren PPAH. Tepat sebelum acara diakhiri, tim meminta kesediaan para santri yang memang berminat untuk mengikuti rangkaian kegiatan pengabdian ini.

\section{Tahap Pelatihan dan Penyuluhan Keterampilan Sablon Digital}

Dari kegiatan sosialisasi, terjaring 75 santri yang berminat untuk mengikuti kegiatan pengabdian ini. Kegiatan pelatihan dilaksanakan di akhir bulan Juli selama 2 hari. Hari pertama berisi materi tentang kewirausahaan dan materi tentang Ekonomi Kreatif yang disampaikan secara bersama oleh tim pengabdian. Selain itu, di hari pertama ini juga disampaikan materi tentang dunia printing (sablon) dari yang sistem manual sampai berbentuk digital seperti sekarang ini. Hari pertama ditutup dengan melakukan praktek pencetakan gambar pada media kaos menggunakan teknik press poliflex. Hari kedua pelatihan diisi dengan pelatihan memindahkan gambar pada kertas sublime yang juga diprint dengan tinta sublime ke media mug dan kaos.

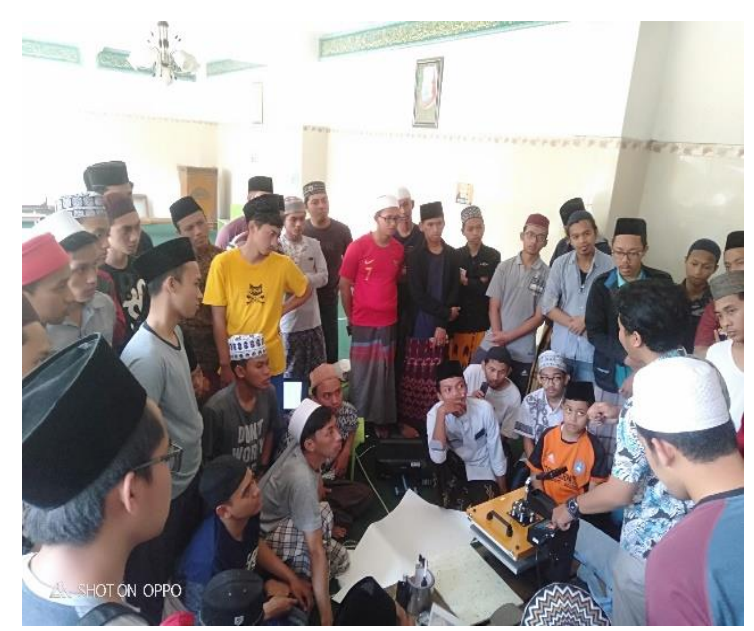

Gambar 3. Suasana pelatihan

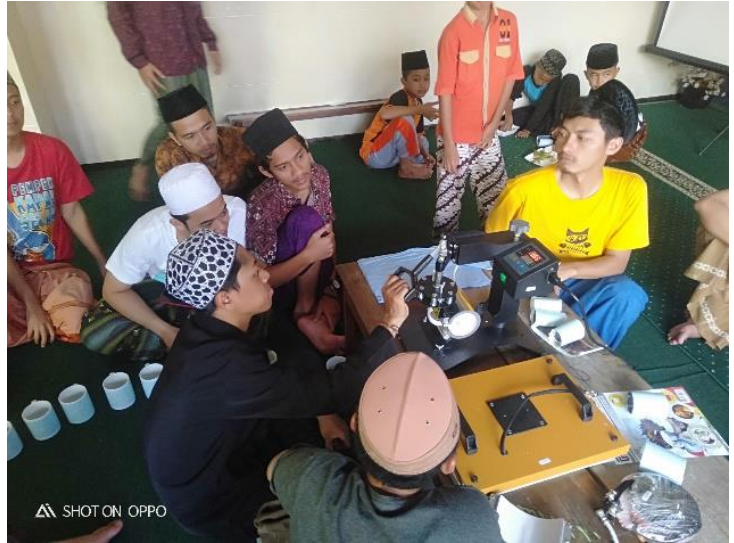

Gambar 4. Para santri melakukan praktik

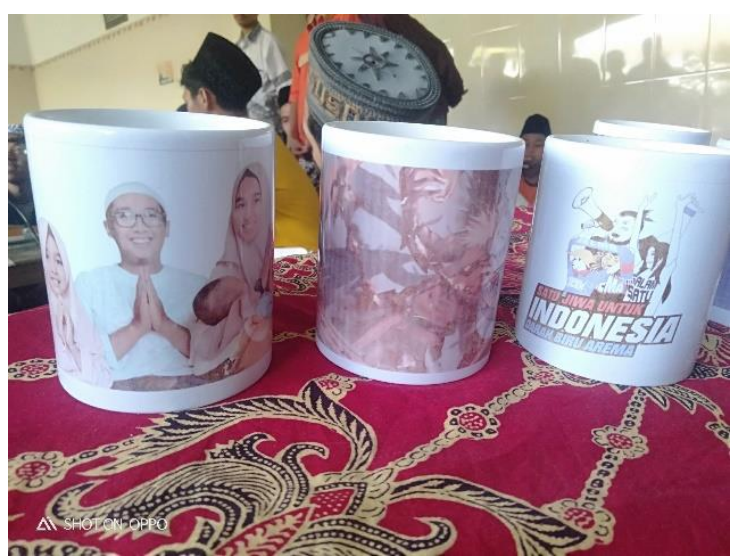

Gambar 5. Hasil Praktek pada Media Mug

Pelaksanaan pengabdian kepada masyarakat terkait dengan peningkatan wawasan kewirausahaan kepada para santri di PPAH mendapatakan hasil yang cukup memuaskan. Hasil survey dengan menggunakan teknik kuesioner (Pre-test dan Post-test) menunjukkan bahwa setelah pelatihan, keinginan para santri untuk menjadi seorang santripreneur dan pengetahuan mereka tentang kewirausahaan meningkat. Kuesioner ditujukan kepada para santri yang menjadi peserta pelatihan, yakni sebanyak 75 orang. Hasil kuesioner tersebut ditunjukkan oleh tabel 1.

Hasil post-test dan pre-test menunjukkan bahwa para santri mengalami peningkatan dalam hal wawasan kewirausahaan dan minat beriwirausaha setelah mengikuti kegiatan pelatihan dan penyuluhan.

Indikator pertama adalah terkait dengan wawasan kewirausahaan. Indikator ini berisi tentang bagaiamana sebenarnya 
pemahaman para santri PPAH terkait dengan kewirausahaan dan menjadi wirausaha. Pada tahap pre-test, skor ratarata para santri dalam indicator ini adalah sebesar 56,31. Peningkatan terjadi setelah para santri mengikuti pelatihan dan penyuluhan yakni menjadi 81,23 atau selisihnya sebesar 24,92.

Tabel 1. Hasil Pre-test dan Post-test

\begin{tabular}{|c|c|c|c|c|}
\hline \multirow{2}{*}{ No. } & \multirow{2}{*}{ Indikator } & \multicolumn{2}{|c|}{$\begin{array}{c}\text { Rata-rata } \\
\text { Skor }\end{array}$} & \multirow{2}{*}{$\begin{array}{l}\text { Selisih } \\
\text { skor }\end{array}$} \\
\hline & & $\begin{array}{l}\text { Pre } \\
\text { Test }\end{array}$ & $\begin{array}{l}\text { Post } \\
\text { Test }\end{array}$ & \\
\hline 1 & $\begin{array}{l}\text { Pengetahuan } \\
\text { tentang } \\
\text { kewirausahaan }\end{array}$ & 56,31 & 81,23 & 24,92 \\
\hline 2 & $\begin{array}{l}\text { Minat } \\
\text { Berwirausaha }\end{array}$ & 70,23 & 88,87 & 18,64 \\
\hline 3 & $\begin{array}{l}\text { Pengetahuan } \\
\text { tentang } \\
\text { Ekonomi } \\
\text { Kreatif }\end{array}$ & 60,24 & 88,21 & 27,97 \\
\hline 4 & $\begin{array}{l}\text { Minat } \\
\text { berwirausaha } \\
\text { di Industri } \\
\text { Kreatif }\end{array}$ & 77,23 & 97,26 & 20,03 \\
\hline 5 & $\begin{array}{l}\text { Kepemimpinan } \\
\text { dan } \\
\text { Manajemen } \\
\text { Usaha }\end{array}$ & 69,2 & 80,32 & 11,2 \\
\hline
\end{tabular}

Pada indikator minat berwirausaha, sebenarnya terlihat bahwa skor pada saat pre-test tidak terlalu buruk, yakni 70,23. Artinya, para santri sebenarnya sudah memiliki kecenderungan untuk memiliki usaha sendiri. Hal ini kemudian diperkuat dengan pemberian materi tentang kewirasusahaan sehingga skor pada saat post-test naik 18,64 poin menjadi 88,87.

Indikator pengetahuan wawasan Ekonomi Kreatif perlu kami lihat karena memang Program Pengabdian ini berbasis ekonomi kreatif, yakni pelatihan digital printing. Secara reratanya, skor untuk pengetahuan para santri terkait Ekonomi Kreatif sebelum dilaksanakannya kegiatan pengabdian adalah 60,24. Aspek ini mengalami peningkatan yang pesat karena setelah post-test skornya menjadi 88,21 atau naik sebesar 27,97 dari nilai pretestnya.

Selain minat berwirausaha secara umum, kami juga melihat indicator untuk minat usaha di bidang industri kreatif. Dari hasil kuis didapatkan bahwa sebagian besar santri peserta program pengabdian memiliki minat yang lumayan tinggi di bidang ekonomi kreatif bahkan sebelum ada pelatihan, yakni sebesar 77,23. Setelah dibekali keterampilan sablon dengan teknik digital, terlihat bahwa antusiasme para santri menjadi santripreneur di bidang Ekonomi Kreatif meningkat cukup pesat menjadi 97,26.

Aspek terakhir yang dilihat dari para santri adalah aspek kepemimpinan dan kemampuan manajemen Usaha. Indikator ini merupakan indikator yang masih harus terus ditingkatkan jika dibandingkan dengan indikator lainnya. Skor post test yang 'hanya' 80,32 dari sebelumnya 69,2 menggambarkan bahwa sikap kepemimpinan dan manejemen usaha para santri harus terus dilatih. Namun, aspek ini memang hanya bisa ditingkatkan saat mereka benar-benar menjadi santripreneur.

\section{Tahap Pendampingan}

Pendampingan dilaksanakan untuk membantu dan mengarahkan para santri untuk merintis dan mengembangkan usahanya sehingga menjadi santripreneur yang benar-benar siap menghadapi persaingan. Tabel 2 merinci daftar pelaksanaan pendampingan beserta agenda yang dilaksanakan.

Kegiatan pendampingan menghasilkan keputusan bahwa pondok pesantren akan membuka usaha cetak dan penjualan souvenir yang memanfaatkan sablon digital sebagai metodenya. Selain itu, tim juga telah membentuk tim yang berisikan 5-6 orang santri yang akan melaksanakan kegiatan operasional usaha tersebut. Barang-barang hasil produksi santri nantinya akan dipasarkan melalui sistem online dan offline dengan 
memajangnya di toko ATK yang sebelumnya sudah dimiliki oleh PPAH.

Tabel 2. Kegiatan Pendampingan

\begin{tabular}{clr}
\hline Pertemuan Ke- & \multicolumn{2}{c}{ Bentuk Kegiatan } \\
\hline & Koordinasi dengan \\
pengasuh dan pengurus \\
I & Pondok Pesantren Anwarul \\
& Huda \\
& Pemberian materi oleh tim, \\
& tentang: Konsep Dasar \\
II & Kewirausahaan dan \\
& Pengelolaan Usaha. \\
III & Persiapan Pembentukan \\
& Usaha \\
IV & Pelayanan Bimbingan dan \\
& Pendampingan Usaha \\
V & Pelayanan Bimbingan dan \\
& Pendampingan Usaha \\
\hline
\end{tabular}

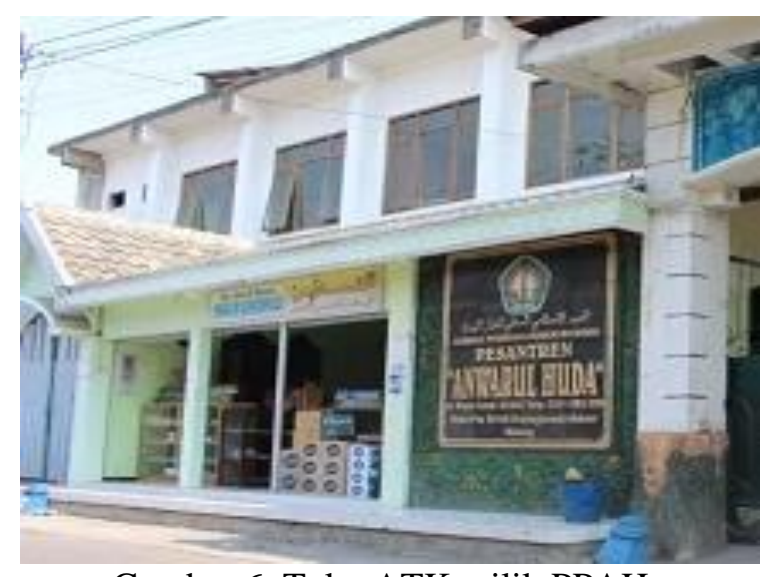

Gambar 6. Toko ATK milik PPAH

\section{SIMPULAN}

Dari hasil pelaksanaan seluruh rangkaian pengabdian kepada masyarakat ini, kita bisa simpulkan bahwa pesantren memiliki potensi yang sangat besar dalam rangka meningkatkan kesejahteraan ekonomi. Terlepas dari pandangan masyarakat yang masih banyak menganggap bahwa pesantren hanyalah tempat untuk menimba ilmu agama, pesantren sebenarnya bisa menjadi ujung tombak bagi terciptanya individu yang mumpuni dalam bidang agama sekaligus mapan di bidang ekonomi.

Pelaksanaan kegiatan pengabdian yang berbasis peningkatan pengetahuan dan skill para santri di bidang industri kreatif yang dalam hal ini adalah sablon digital bisa dikatakan mencapai keberhasilan dengan meningkatnya wawasan dan minat para santri untuk berwirausaha. Kemandirian pesantren juga bisa semakin meningkat dengan adanya unit usaha baru di pesantren yang menjadi pemasukan bagi pesantren dan digunakan untuk keberlangsungan lembaga pesantren.

Kegiatan pengabdian ini pada dasarnya masih bisa dilanjutkan agar tercipta kesinambungan yakni dengan cara menjadikan unit-unit usaha di Pondok Pesantren Anwarul Huda (PPAH) menjadi UKM binaan dari Universitas Negeri Malang (UM). Dengan kata lain, mekanisme simbiosis mutualisme antara PPAH dan UM akan terus berlangsung.

\section{UCAPAN TERIMA KASIH}

Ucapan terimakasih disampaikan oleh tim penulis artikel ini kepada Univeritas Negeri Malang (UM). Pengabdian kami yang berjudul asli "Pemberdayaan Santri Pondok Pesantren di Bidang Ekonomi Kreatif Demi Menciptakan Santripreneur" dapat terlaksana dengan baik dan lancar berkat bantuan dana hibah dari Universitas Negeri Malang. Tim penulis menyadari bahwa tanpa bantuan dana dari UM, kegiatan ini tidak akan berjalan sebagaimana target yang direncanakan oleh tim.

\section{DAFTAR PUSTAKA}

Suyatman, U. (2017). Pesantren Dan Kemandirian Ekonomi Kaum Santri (Kasus Pondok Pesantren Fathiyyah Al-Idrisiyyah Tasikmalaya). Al-Tsaqafa: Jurnal Ilmiah Peradaban Islam, 14(2), 303-314.

Wadi, M. (2018). Potensi dan peran pesantren dalam mengembangkan ekonomi masyarakat: studi pada Pondok Pesantren Miftahul Ulum Panyeppen Pamekasan (Doctoral 
M.H.I. Abbas, dkk. SANTRIPRENEUR: Program Peningkatan Kemampuan ........

dissertation, UIN Sunan Ampel Surabaya).

Rudi, L., \& Haikal, H. (2014). Modal Sosial Pendidikan Pondok

Pesantren Social Capital Of

Boarding School

Education. Harmoni Sosial: Jurnal Pendidikan IPS, 1(1).

Muttaqin, R. (2016). Kemandirian dan pemberdayaan ekonomi berbasis pesantren (studi atas peran Pondok Pesantren Al-ittifaq Kecamatan Rancabali Kabupaten Bandung terhadap kemandirian eknomi santri dan pemberdayaan ekonomi masyarakat sekitarnya). JESI (Jurnal Ekonomi Syariah Indonesia), 1(2), 65-94. 